\title{
VIEWPOINTS
}

\section{Addressing the Haze: The Role of Local Traditional Cultures and Islamic Teachings}

\author{
Shahino Mah Abdullah*
}

\section{Transboundary Haze}

The most frequent transboundary haze in the world takes place in Southeast Asia. It is usually caused by land-use changes, open burning, peat combustion, wildfires, and other farming activities. Serious haze occurred in 1983, 1997, 2005, 2006, 2009, 2010, 2013, 2015 and 2016, originating from large-scale forest fires in western Sumatra and southern Kalimantan, Indonesia. It caused adverse effects to locals as well as neighbouring countries, affecting their health, economy, agriculture, and biodiversity. Among the serious effects of haze are increased respiratory-related mortality due to toxic airborne particles, jet crashs and ship collisions due to restricted visibility, reduction of crop growth rate due to limited solar radiation, and extinction of endangered primates due to habitat loss. Neighbouring countries like Malaysia and Singapore sometimes have to close schools to prevent people from being exposed to air pollution, and its consequent respiratory ailments.

Transboundary haze caused by forest fires in Indonesia has been an annual problem due to the widespread use of the easy and cheap method of 'slash-andburn' to clear the land. This is claimed to be a traditional farming method practised since long ago and still in use today by farmers and corporations in the pulpwood and palm oil industry. According to Herry Purnomo, a professor at Indonesia's Bogor Agricultural University, there are two main offenders: poor small-scale farmers who attempt to expand their farmland, and scoundrel operators who intend to clear forests illegally for land acquisition. He also highlighted the role of influential patronage networks involving some local Indonesian elites, village elites, and individuals who are responsible for such practices. 


\section{Importance of Ethical Values in Addressing Haze Issues}

There are several possible preventive measures that the authorities can implement with the support of the people. For instance, the elimination of market demand for illegal land for plantation could mitigate deforestation. The authorities can also make pledge funds a mandatory requirement for companies to ensure fire prevention, as well as enforce strict fines and punishments for lawbreakers. There is also a necessity to establish and empower an anti-corruption body to work against patronage networks to ensure efficient government bureaucracy. Last but not least, the authorities and stakeholders must develop and provide clear plans for landholders to manage their land sustainably.

These measures are certainly predicated on crucial ethical values and regard for the rule of law by every individual, despite their position in society. In this respect, the standard-setting action in the field of bioethics is pivotal and indispensable. Most importantly, all people, including government leaders and stakeholders, must follow and adopt the ethical benchmark as outlined in the 'Universal Declaration on Bioethics and Human Rights' (UDBHR). This declaration, drafted by UNESCO in consultation with the Intergovernmental Bioethics Committee, can be a guideline for policymakers to enhance laws and regulations. Some of the main provisions of the UDBHR highlight the importance of appropriate utilisation of resources that encompass the people's role in the protection of the environment (Article 17). Also highlighted was the establishment of an ethics committee to assess scientific developments and provide advice on ethical and legal problems in clinical settings (Article 19). These provisions could be the key points to consider, revisit and promote in order to address haze-related issues, including curbing climate change.

In the past, traditional Malay advice, recommendations, guidelines and prohibitions emphasised the purpose and reason behind human action. The messages they brought were not limited to the betterment of individuals and societal life. They also included the right manner of interaction between human beings and the environment so that none of the former's deeds would be meaningless and harmful. The new generation should learn those precious values and appreciate the lessons they receive. In the case of haze in Southeast Asia, the 'slash-and-burn' method adopted by irresponsible individuals, farmers and companies in clearing the land for various profitable purposes is contrary to the objectives of the original traditional practice. The traditional practice to clear the land in the Malay Archipelago did not aim for profit maximisation; It was intended to fulfil the needs of the local community for food through traditional sustainable farming, as well as help build homes, boats and other amenities using felled wood obtained from the land-use. 


\section{Preservation of the Environment from the Islamic Perspective}

The local community in the Malay Archipelago mostly adhere to Islamic values. For them, Islam has become the way of life, shaping their traditional culture while also marking their identity. Islamic teachings have spread throughout the Malay world and are generally well accepted by the people; Islam remains dominant in the region, especially in Indonesia and Malaysia. Islamic teachings address the human-Earth relationship through a set of principles namely tawhid (Divine Oneness), khalifah (vicegerency of man), and amanah (trusteeship). Tawhid is manifested in the unity of God's creation, which includes men, women, animals and the whole universe that exist in balance. It also means that the human being is part of a natural equilibrium that must not be disturbed. The principle of khalifah implies that human beings hold a position of power, trust and responsibility to build the earth. It also entails human responsibility to safeguard the rights of fellow humans, nature and other inhabitants of the Earth. Amanah, which is an integral part of the faith and personality of a Muslim, highlights the entrusted role of human beings as custodians of the Earth. The most important of all amanat is justice ( ' $a d l$ ), the doing of good ( $i$ hsan) towards fellow humans and the natural environment. Furthermore, these principles lead to the concept of $i$ mar al-ard (building of the earth) that encourages human progress in developing the earth without compromising environmental wellbeing.

The practical approach to leveraging natural resources must be set right and made sustainable via the above principles. In Southeast Asia, the 'slash-and-burn' technique should be banned to address the spread of wildfires. A new technique of land clearing such as forestry mulching with the use of green technology may be considered. There is a need also to improve the consumption of resources by practising moderation (wasatiyyah), thereby promoting efficient consumption of resources while reducing wastage and pollution. In terms of environmental issues, human must make an effort to manage natural resources, not only as consumers, but also as vicegerents of the Earth (khalifah). In Islam, it is important to keep the ecosystem in balance (mizan). It is also advisable to include a holistic framework that integrates religious aspects in the conceptual model of the built environment by taking maqasid al-shari 'ah (higher objective of Islamic law) as a guide. The maqasid highlight the importance of preserving five essential goals: faith (din), life (nafs), progeny (nasl), intellect ('aql), and property ( $m a l)$. The advancement of a maqasidi discourse has also placed renewed emphasis on environmental preservation (hifz al-bi'ah). 


\section{Towards a Sustainable Community Development}

Religious principles contain wisdom that is worth sharing between communities and the whole of humanity. Besides, the promotion of traditional wisdom, they could encourage the locals to manage their surrounding environment in the most sustainable way while maintaining their original identity. It is of great importance for them to inculcate a sense of belonging, especially to the land they reside in and their 'environmental preservation' identity. Conscientious restoration works are necessary to fill in the subtle loopholes as their environmental wisdom has gone through the long process of inheritance across generations. In this case, the role of the international ethics committee and local scholars is crucial to guide them to address ethical and legal issues. At the same time, it is necessary to consider the 'sustainable community development' approach in addressing environmental and societal issues. It is an important component to ensure sustainability in community survival and development since those who are poor and hungry will often destroy their immediate environment to survive, as stated in the Brundtland Report. Therefore, it is highly recommended to synergise the model of 'sustainable community development' with the traditional wisdom of the local people, as well as Islamic teachings on the role of human beings, in our effort to address transboundary haze issues and to meet the objectives of the UN Sustainable Development Goals.

* Shahino Mah Abdullah is a Research Fellow at the International Institute of Advanced Islamic Studies (IAIS) Malaysia. He can be contacted at shahino@ iais.org.my. 